\title{
Beta-Adrenergic Receptors and Isoproterenol- stimulated Potassium Transport in Erythrocytes from Normal and Hypothyroid Turkeys
}

\author{
QUANTITATIVE RELATION BETWEEN RECEPTOR OCCUPANCY AND \\ PHYSIOLOGIC RESPONSIVENESS
}

\author{
Haruyasu Furukawa, John N. Loeb, and John P. Bilezikian, \\ Department of Medicine, Columbia University College of Physicians b Surgeons, \\ New York 10032
}

\begin{abstract}
A B S T RACT We have previously reported that in hypothyroid turkeys the number of beta-adrenergic receptors in intact erythrocytes is reduced by $\sim 50 \%$ without any changes in the affinity of the receptor for the agonist, isoproterenol. In view of the physiological action of the catecholamines to stimulate bidirectional ion fluxes in these cells, we have now examined the possibility that the decrease in beta receptor number might be associated with concomitant changes in catecholamine-dependent potassium ion transport. Hypothyroid turkey erythrocytes display decreased sensitivity to isoproterenol-stimulated potassium influx. Half-maximal stimulation of potassium influx occurs at $9.2 \pm 1.7 \mathrm{nM}$ in hypothyroid cells as opposed to only $3.8 \pm 0.4 \mathrm{nM}$ in normal cells $(P<0.005)$. A maximal stimulatory concentration of isoproterenol $(100 \mathrm{nM})$ leads to the same increment in ion flux in erythrocytes from hypothyroid and normal turkeys. Analysis of the quantitative relationship between isoproterenol concentration, receptor occupancy, and associated effects upon potassium influx shows that at low levels of isoproterenol, where occupancy is linear with agonist concentration, occupation of a given number of beta receptors leads to a stimulation of potassium transport that is identical in erythrocytes from normal and hypothyroid turkeys. Thus, decreased sensitivity to catecholamine-stimulated potassium transport in hypo-
\end{abstract}

An abstract of this work was presented at the Annual Meeting of the American Society for Clinical Investigation, Washington, D. C., in 1980. Clin. Res. 28: 478A.

Dr. Bilezikian is the recipient of Research Career Development Award HL-00383.

Received for publication 10 March 1980 and in revised form 16 June 1980. thyroidism can be attributed to the decrease in receptor number and the resulting two- to threefold higher isoproterenol concentration required for occupancy of the same number of beta receptors. Once a single receptor is occupied, however, the more distal components of the sequence of events mediating the physiological response to beta-adrenergic agonists in the hypothyroid cell function as they do under normal circumstances. It would appear, therefore, that the decrease in sensitivity to isoproterenol-dependent ion flux in the hypothyroid turkey erythrocyte can be accounted for solely by the decrease in receptor number. These changes are shown to occur in the absence of any modifications in the number of $\mathrm{Na}^{+}-\mathrm{K}^{+}$ ATPase effector units per cell.

\section{INTRODUCTION}

It has long been a familiar clinical observation that beta-adrenergic tone is increased in hyperthyroidism and decreased in hypothyroidism (1). To account for these observations, early studies were directed at a number of physiological and enzymatic aspects of adrenergic action and yielded variable results $(2,3)$. More recently, the availability of appropriate radioligands has made it possible to examine the initial site of catecholamine action by direct measurement of beta receptor number. In some (4-13) but not all (13-15) studies, hyperthyroidism has been associated with an increased number of beta receptors and hypothyroidism with a decreased number of beta receptors. These latter investigations, however, have been limited mainly to a description of the beta receptor itself or the beta receptor-adenylate cyclase complex, 
and they have not included an examination of possible physiological correlates of changes in beta receptor number $(4-13,15)$. To this end, it has been desirable to study an experimental tissue that not only possesses a beta-adrenergic receptor but that additionally exhibits a characteristic and readily measurable physiological response to beta-adrenergic agonists in vitro. The turkey erythrocyte satisfies these criteria by having a well-defined beta-adrenergic receptor and by responding to beta-adrenergic agonists with increased adenylate cyclase activity, cyclic AMP generation, and a cyclic AMP-linked enhancement of monovalent cation transport $(16,17)$. This latter enhancement of monovalent cation transport is resistant to ouabain and sensitive to furosemide and represents, most likely, an activation of a sodium-plus-potassium cotransport pathway (18).

We have reported recently that experimentally induced hypothyroidism in the turkey is associated with a $50 \%$ reduction in the number of beta-adrenergic receptors per erythrocyte, and that this reduction in receptor number is associated with proportional decreases in maximal catecholamine-dependent adenylate cyclase activity and cellular cyclic AMP accumulation (13). These studies did not, however, address the possibility that a decrease in beta-adrenergic receptors might be associated with concomitant changes in the physiological action of the catecholamines to stimulate bidirectional ion fluxes in these cells. Direct experiments were required to test this possibility because of recent demonstrations that occupation of only $10 \%$ of the total number of beta receptors in the turkey erythrocyte is sufficient for maximal effects on potassium influx $(19,20)$. In the present study, we have specifically examined the quantitative relationship between the occupation of beta receptors by isoproterenol and stimulation of potassium transport in erythrocytes from normal and hypothyroid turkeys. We have found that physiological responsiveness of hypothyroid turkey erythrocytes to isoproterenol is reduced, and that this decreased sensitivity, resulting in a shift in the isoproterenol concentration-response curve, can be accounted for by the known reduction in beta-adrenergic receptor number. The changes in ion fluxes observed here, in contrast to the effects of thyroid hormone on ion pumps in many other tissues (21), occur in the absence of any changes in the number of ion pump units per cell.

\section{METHODS}

Maintenance of turkeys. White female turkeys were maintained, housed, and fed according to our published protocol (13). Hypothyroidism was induced by radiothyroidectomy or by the provision of a low-iodine diet (22) and sodium perchlorate. As shown previously, the hypothyroid state was confirmed both by clinical observations and by measurement of low thyroid hormone levels $(13,23)$.

Preparation of washed erythrocytes. Heparinized blood (generally a 5-ml sample) was obtained by syringe from a wing vein. After centrifugation at $400 \mathrm{~g}$ for $10 \mathrm{~min}$ the plasma was removed and the erythrocytes were resuspended in incubation buffer containing $150 \mathrm{mM} \mathrm{NaCl}, 10 \mathrm{mM} \mathrm{KCl}$, $11.1 \mathrm{mM}$ glucose, and $10 \mathrm{mM}$ Tris at $\mathrm{pH} \mathrm{7.4}$. After resedimentation of the erythrocytes and two further washes, the cells were resuspended in incubation buffer and kept on ice. Hemoglobin was measured by the cyanmethemoglobin method (24).

Measurement of ${ }^{42} \mathrm{~K}^{+}$influx. Potassium influx was determined by a minor modification of the method of Gardner et al. (25). Washed turkey erythrocytes were preincubated for $2 \mathrm{~h}$ at $37^{\circ} \mathrm{C}$ in medium identical in composition to that to be used in the subsequent influx measurements except for the absence of the radioactive tracer ${ }^{42} \mathrm{~K}^{+}$. After preincubation, centrifugation, and washing of the cells, aliquots of washed, packed cells were transferred to capped scintillation vials in a shaking water bath at $37^{\circ} \mathrm{C}$ containing prewarmed incubation medium and ${ }^{42} \mathrm{~K}^{+}\left(0.11-0.19 \mathrm{mCi} / \mathrm{mg} \mathrm{K}{ }^{+}\right.$; New England Nuclear, Boston, Mass). Other agents such as (-)isoproterenol, ouabain (Sigma Chemical Co., St. Louis, Mo.) or (-)-propranolol (Ayerst Laboratories, New York, N. Y.) are specified in individual experiments. Final hematocrits in the resulting incubation mixtures ranged between 5 and $10 \%$. At specified times $100-\mu$ l aliquots of the incubation mixtures were transferred to plastic tubes containing $300 \mu$ l of chilled incubation medium, and the erythrocytes were immediately centrifuged down in a Beckman Microfuge (Beckman Instruments, Inc., Palo Alto, Calif.). After aspiration of the supernatant fluid, the erythrocytes were resuspended in $300 \mu \mathrm{l}$ of fresh cold medium and resedimented. After two additional identical washings, each plastic tube containing the final washed erythrocyte pellet was placed in a $12 \times 75-\mathrm{mm}$ glass tube. The radioactivity was determined directly in a scintillation spectrometer (Packard Instrument Co., Inc., Downers Grove, Ill.). Potassium influx both in the presence and absence of isoproterenol was shown to be linear with time for at least $30 \mathrm{~min}$. Influx was therefore routinely determined by the difference between zero-time and 30-min samples in triplicate. The range of variation between triplicate samples by this method was extremely narrow, maximal variation rarely exceeding $2 \%$. Radioactivity in zero-time samples was similarly low, and generally $<2 \%$ of that present after $30 \mathrm{~min}$ of incubation.

Binding of $\left[{ }^{3} \mathrm{H}\right]$ ouabain. Suspensions of washed erythrocytes were added to glass scintillation vials containing incubation medium and $\left[{ }^{3} \mathrm{H}\right]$ ouabain $(12-20 \mathrm{Ci} / \mathrm{mmol}$; New England Nuclear) either in the presence or absence of an additional displacing concentration of nonradioactive ouabain as indicated below. Stock $\left[{ }^{3} \mathrm{H}\right]$ ouabain in 9:1 ethanol: benzene was evaporated to dryness under nitrogen and redissolved in buffer before use. A known concentration of nonradioactive ouabain was added to reduce the specific activity of the radioligand to a range of $1.5-3.5 \mathrm{Ci} / \mathrm{mmol}$. The vials were then capped, and the resulting suspensions, at a final hematocrit ranging between 3 and $5 \%$, were incubated in a shaking water bath at $37^{\circ} \mathrm{C}$. Ouabain binding to erythrocyte membranes was determined by transferring duplicate $100-\mu \mathrm{l}$ aliquots of incubation mixture to $5 \mathrm{ml}$ of distilled water at $0^{\circ} \mathrm{C}$, vortexing the mixture, and trapping the hemolyzed erythrocyte membranes on Gelman A/E glass filters (Gelman Sciences, Inc., Ann Arbor, Mich.). The filters were washed four times with additional 5-ml portions of iced distilled water and transferred to glass scintillation vials, 
and radioactivity was determined in a liquid scintillation spectrometer in $10 \mathrm{ml}$ of Bray's solution (26).

Binding of $\left[{ }^{125} I\right]$ iodohydroxybenzylpindolol $\left(\left[{ }^{125} I\right]\right.$ IHYP). ${ }^{1}$ The binding of $\left.{ }^{125} \mathrm{I}\right] \mathrm{IHYP}(2,200 \mathrm{Ci} / \mathrm{mmol}$; New England Nuclear) to intact turkey erythrocytes was determined according to our published method (13). Freshly obtained, washed, turkey erythrocytes $\left(2.5 \times 10^{7} / \mathrm{ml}\right)$ were incubated with [ $\left.{ }^{125} \mathrm{I}\right] \mathrm{IHYP}(40 \mathrm{pM})$ and a range of (-)-isoproterenol concentrations $(10 \mathrm{nM}-5 \mu \mathrm{M})$ for $30 \mathrm{~min}$ at $37^{\circ} \mathrm{C}$ in a buffer containing $\mathrm{NaCl}(150 \mathrm{mM}), \mathrm{KCl}(10 \mathrm{mM})$, glucose $(11.1 \mathrm{mM})$, ascorbate $(0.1 \mathrm{mM})$, and Tris- $\mathrm{HCl}(10 \mathrm{mM}, \mathrm{pH} 7.4) .100-\mu \mathrm{l}$ samples were removed in triplicate, immediately filtered over Gelman A/E glass filters and washed with 12-ml of Tris buffer $(10 \mathrm{mM}, \mathrm{pH} 7.5)$ at room temperature. Filters with erythrocytes and ligand bound to them were counted in an Auto-Gamma spectrometer. Specific binding, defined as the component of total binding inhibitable by $0.5 \mathrm{mM}(-)$ isoproterenol, was $\sim 60 \%$ of the total binding ( $35 \%$ of the radioactivity filtered). The assay blank (radioactivity trapped on the filter in the absence of cells) was $1 \%$.

Intracellular concentrations of potassium and sodium. These concentrations were determined according to the method of Sachs and Welt (27).

\section{RESULTS}

Characteristics of active potassium influx in erythrocytes from normal and hypothyroid turkeys. We have previously demonstrated that ouabain binds to turkey erythrocytes and inhibits potassium influx with equal affinities, and that these actions of ouabain depend on the external potassium concentration (20). The first series of experiments in the present study was designed to examine the magnitude of basal potassium influx and its sensitivity to inhibition by ouabain in normal and hypothyroid turkeys. As shown in Table I, both the absolute rates of potassium influx in the presence and absence of ouabain ( $1 \mathrm{mM})$ and the degree to which ouabain inhibited basal potassium influx at widely different potassium concentrations were the same in normal and hypothyroid turkeys. Erythrocytes from these two groups of turkeys showed identical sensitivities to ouabain with half-maximal inhibition of basal potassium influx occurring at $0.27 \mu \mathrm{M}\left(\left[\mathrm{K}^{+}\right]\right.$ $=0.7 \mathrm{mM})$ and at $4.0 \mu \mathrm{M}\left(\left[\mathrm{K}^{+}\right]=10 \mathrm{mM}\right)$ in each case (Fig. 1). Scatchard analysis (28) of ouabain binding (Fig. 2) showed, furthermore, that binding affinity as well as binding capacity were indistinguishable. For cells from both normal and hypothyroid turkeys the equilibrium dissociation constant, $K_{d}$, for ouabain was $0.25 \mu \mathrm{M}\left(\right.$ at $\left.\left[\mathrm{K}^{+}\right]=0.6 \mathrm{mM}\right)$ and the binding capacity was $55 \mathrm{pmol} / \mathrm{ml}$ packed cells. (This latter value corresponds to $\sim 4,500 \mathrm{Na}-\mathrm{K}^{+}$-ATPase $\mathrm{U} /$ cell [20].) In further studies, intracellular sodium $(3.8 \pm 0.2 \mathrm{vs}$. $3.7 \pm 0.3 \mathrm{meq} / \mathrm{liter}$ cells) and potassium (115 $\pm 2 \mathrm{vs}$. $116 \pm 1 \mathrm{meq} / \mathrm{liter}$ cells) ion concentrations in euthyroid

\footnotetext{
${ }^{1}$ Abbreviation used in this paper: [ $\left.{ }^{125} \mathrm{I}\right] \mathrm{IHYP}, \quad\left[{ }^{125} \mathrm{I}\right]-$ iodohydroxybenzylpindolol.
}

TABLE I

Inhibition of Potassium Influx by Ouabain in Erythrocytes from Normal and Hypothyroid Turkeys

\begin{tabular}{lcc}
\hline & \multicolumn{2}{c}{ Potassium ion concentration } \\
\cline { 2 - 3 } Influx rate & $0.7 \mathrm{mM}$ & $10 \mathrm{mM}$ \\
\hline & \multicolumn{2}{c}{ meq/liter cells/h } \\
Normal & $3.7 \pm 0.2$ & $8.7 \pm 0.7$ \\
Basal & $0.13 \pm 0.02$ & $2.4 \pm 0.3$ \\
+ Ouabain (1 mM) & & \\
Hypothyroid & $3.7 \pm 0.4$ & $11.9^{*}$ \\
Basal & $0.23 \pm 0.02$ & 1.9 \\
+ Ouabain $(1 \mathrm{mM})$ &
\end{tabular}

At each external potassium ion concentration, the degree of inhibition of potassium influx by ouabain was not significantly different for erythrocytes from normal and hypothyroid turkeys $(P>0.05)$. Values indicate means \pm 1 SEM.

* Single experiment using pooled blood from three individual hypothyroid turkeys.

and hypothyroid erythrocytes, respectively, were found to be the same. These intracellular ion concentrations are in close agreement with the data of Gardner et al. (25) for normal turkey erythrocytes. It would appear, therefore, that with respect to basal values of potassium transport, sensitivity to inhibition by ouabain, number of $\mathrm{Na}^{+}-\mathrm{K}^{+}$-ATPase units per cell, and intracellular sodium and potassium concentrations, normal and hypothyroid turkey erythrocytes are indistinguishable.

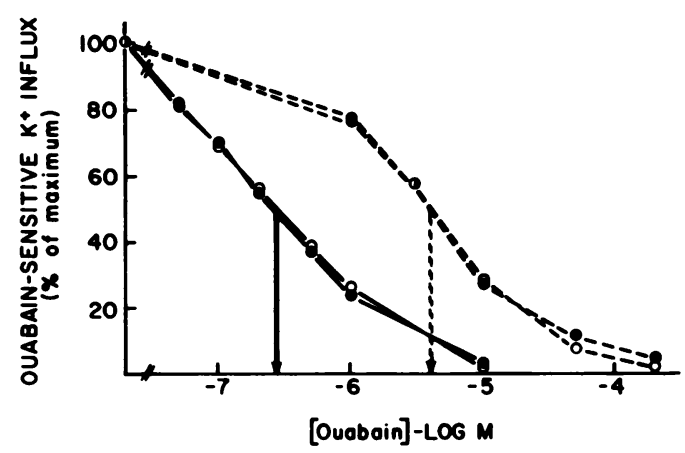

FIGURE 1 Inhibition of basal potassium influx by ouabain in erythrocytes from normal and hypothyroid turkeys. Erythrocytes from normal $(O)$ or hypothyroid $(O)$ turkeys were incubated in the presence of a range of ouabain concentrations and potassium influx was determined (Methods). The data points connected by solid lines were obtained at an external $\mathrm{K}^{+}$concentration of $0.7 \mathrm{mM}$ and those connected by dashed lines were obtained at an external $\mathrm{K}^{+}$concentration of $10 \mathrm{mM}$. Arrows indicate half-maximal inhibition. Values for maximum inhibition by ouabain are shown in Table $I$. 


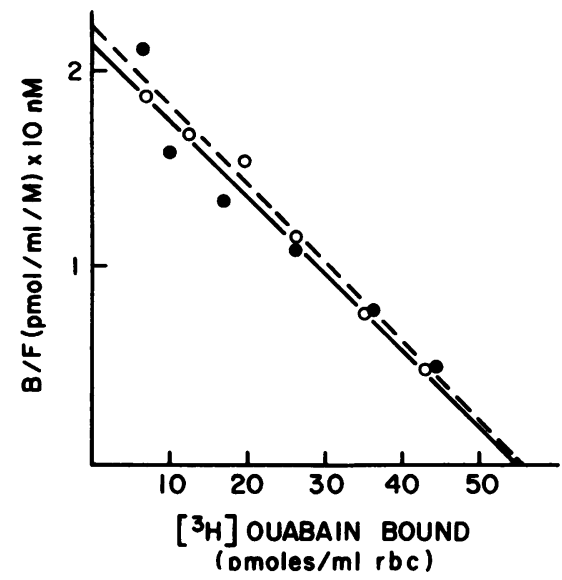

FIGURE 2 Scatchard analysis of the binding of $\left[{ }^{3} \mathrm{H}\right]$ ouabain to erythrocytes from normal and hypothyroid turkeys. A series of $\left[{ }^{3} \mathrm{H}\right]$ ouabain concentrations was used to assess the specific binding of ouabain to normal $(O)$ and hypothyroid $(O)$ turkey erythrocytes (see Methods). The data are plotted according to the method of Scatchard (28). Both maximal binding capacity $(55 \mathrm{pmol} / \mathrm{ml}$ erythrocytes [rbc]) and binding affinity $(0.25 \mu \mathrm{M})$ were indistinguishable between the two groups. $\mathrm{K}^{+}$concentration $=0.6 \mathrm{mM}$.

Physiological responsiveness of normal and hypothyroid erythrocytes to isoproterenol and propranolol: quantitative relationship of isoproterenol-stimulated potassium influx to occupancy of beta-adrenergic receptors. Despite the absence of any demonstrable intrinsic alterations in the active transport system for potassium ion in erythrocytes from the hypothyroid animals, sensitivity to isoproterenol-induced potassium influx was found to be reduced (Fig. 3). Halfmaximal stimulation of potassium influx occurred in normal erythrocytes at an isoproterenol concentration of $3.9 \pm 0.4 \mathrm{nM}$, whereas cells from hypothyroid turkeys

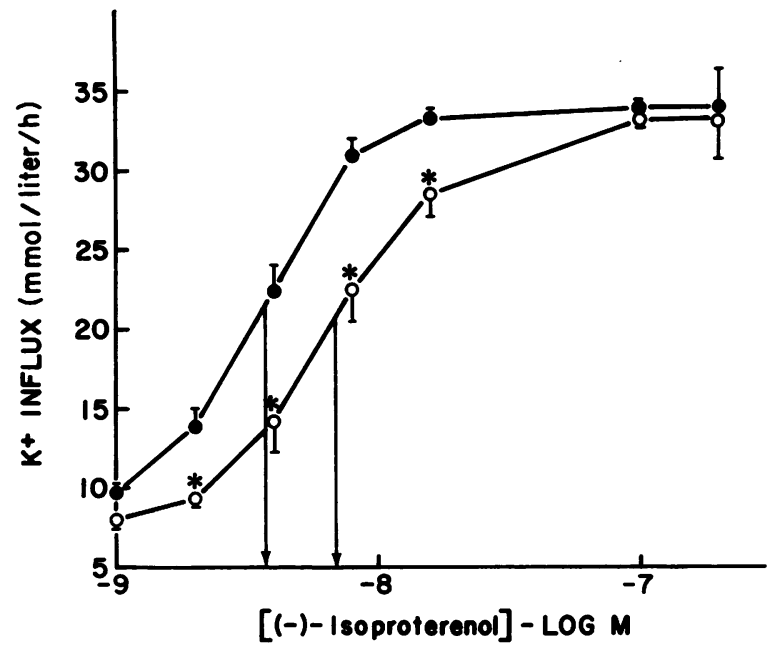

FIGURE 3 Sensitivity of erythrocytes from normal and hypothyroid turkeys to stimulation of $\mathrm{K}^{+}$influx by isoproterenol. Erythrocytes from normal (O) or hypothyroid (O) turkeys were incubated with a range of (-)-isoproterenol concentrations and $\mathrm{K}^{+}$influx was determined according to Methods. For normal erythrocytes, basal and maximally stimulatable $\mathrm{K}^{+}$influxes $([\mathrm{ISO}]=1 \mu \mathrm{M}$ ) were $8.6 \pm 0.5$ and $34 \pm 3 \mathrm{mmol} / \mathrm{liter}$ cells $/ \mathrm{h}$, respectively. For hypothyroid erythrocytes, basal and maximally stimulatable $\mathrm{K}^{+}$influxes were $9.1 \pm 1.7$ and $33 \pm 3$, respectively. The data are shown \pm SEM for $n=14$ (normal) or $n=12$ (hypothyroid) experiments. Asterisks indicate a significant $(P<0.02)$ difference between normal and hypothyroid turkey erythrocytes at the indicated isoproterenol concentrations. Arrows point to the concentrations of $(-)$-isoproterenol required for half-maximal stimulation. $\mathrm{K}^{+}$concentration $\sim 10 \mathrm{mM}$.

required a significantly greater concentration, $9.2 \pm 1.7$ $\mathrm{nM} ; P<0.005$. In contrast to this two- to threefold reduction in sensitivity, the absolute magnitude of the increase in potassium influx induced by a maximally

TABLE II

Effect of Isoproterenol on Potassium Influx in Erythrocytes from Normal and Hypothyroid Turkeys

\begin{tabular}{lrrr}
\hline & \multicolumn{3}{c}{ Potassium ion concentration } \\
\cline { 2 - 4 } \multicolumn{1}{c}{ Influx rate } & $1.12 \mathrm{mM}$ & $2.5 \mathrm{mM}$ & $9.6 \mathrm{mM}$ \\
\hline & & meq/liter cells/h \\
Normal & $5.4 \pm 0.4$ & $6.7 \pm 0.1$ & $8.6 \pm 0.5$ \\
$\quad$ Basal & $13.2 \pm 0.5$ & $20.9 \pm 1.9$ & $34.3 \pm 3.0$ \\
$\quad+$ Isoproterenol $(1 \mu \mathrm{M})$ & & & \\
$\begin{array}{l}\text { Hypothyroid } \\
\text { Basal } \\
+ \text { Isoproterenol }(1 \mu \mathrm{M})\end{array}$ & $13.7 \pm 0.2$ & $5.8 \pm 0.6$ & $7.9 \pm 0.5$ \\
\hline
\end{tabular}

At each potassium ion concentration, both basal and maximal isoproterenol-stimulated influxes were compared between erythrocytes from normal and hypothyroid turkeys. None of the differences was significant by the two-tailed Student's $t$ test $(P>0.1)$. Values indicate means \pm SEM. 
stimulating concentration of isoproterenol was identical for both groups of cells at all concentrations of external potassium ion examined (Table II).

The shift in the isoproterenol sensitivity curve without any change in maximal potassium transport induced by isoproterenol was evaluated in conjunction with our previous demonstration that the number of beta-adrenergic receptors is decreased in hypothyroidism but that the affinity of beta receptors for beta antagonists and beta agonists is unchanged. Binding data for isoproterenol as a competitor of [ ${ }^{125}$ I]IHYP binding indicate an equilibrium binding constant of $0.15-0.2 \mu \mathrm{M}$ for each set of erythrocytes (Fig. 4). These observations suggested that greater fractional occupancy of receptors in hypothyroid cells was required for a given absolute level of stimulated potassium transport. To test this possibility, both potassium influx and absolute beta receptor occupancy were plotted simultaneously against isoproterenol concentration for normal and hypothyroid cells (Fig. 5A). At low concentrations of isoproterenol (well below the $K_{\mathrm{d}}$ for isoproterenol binding), receptor occupancy is very nearly linear with hormone concentration and closely parallels the level of isoproterenol-stimulated potassium influx. For any absolute level of receptor occupancy at these low isoproterenol concentrations, both normal and hypothyroid cells respond with the same amount of potassium influx. Fig. 5B illustrates this conclusion more explicitly by plotting isoproterenol-stimulated potassium influx as a function of

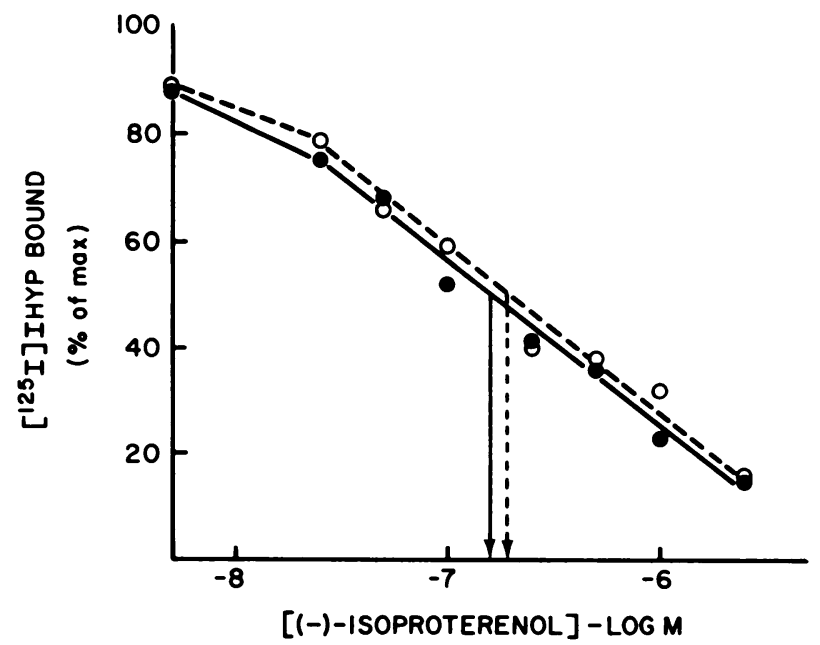

FIGURE 4 Inhibition of [ ${ }^{125}$ I]IHYP binding by (-)isoproterenol in normal and hypothyroid turkey erythrocytes. A series of (-)isoproterenol concentrations was used to determine its ability to compete with [ $\left.{ }^{125} I\right]$ IHYP for beta receptor sites in intact erythrocytes from normal and hypothyroid turkeys. The binding experiments were performed according to Methods. Each data point is the mean of three separate binding experiments.
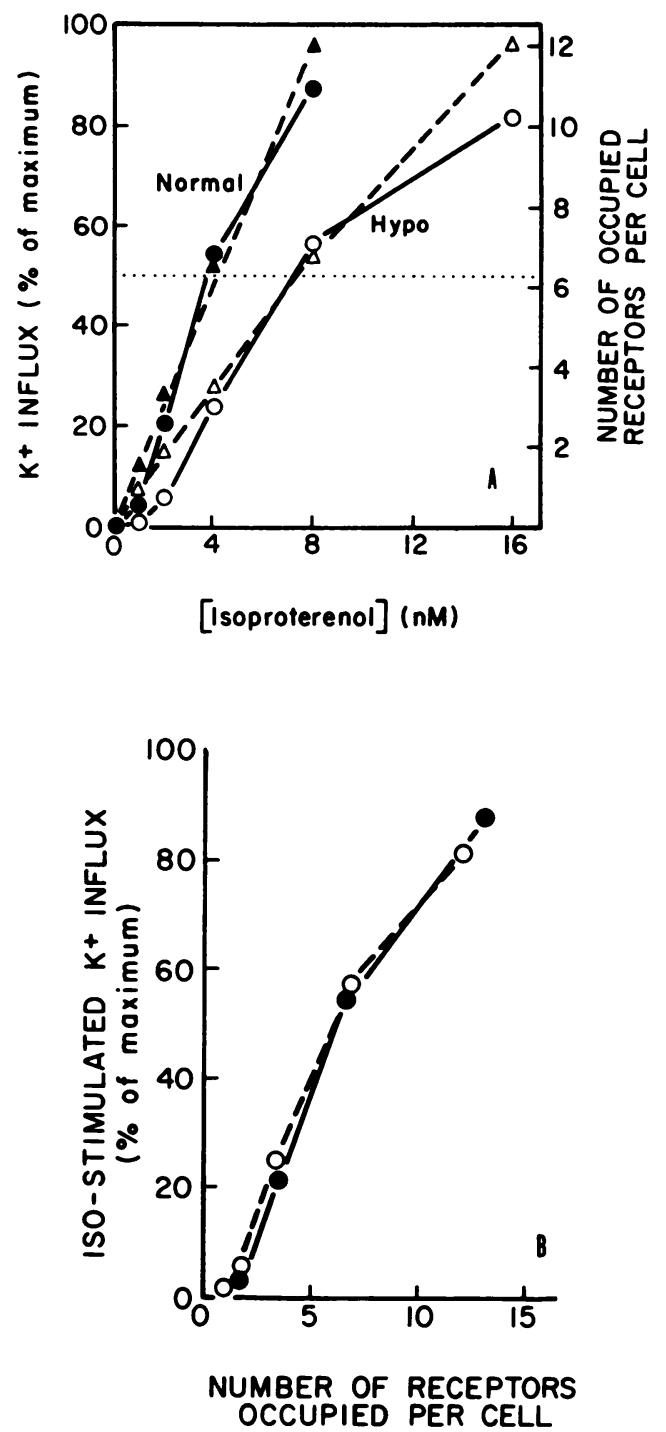

Figure 5 Quantitative relation between occupation of $\beta$-receptors and isoproterenol-stimulated potassium influx in normal and hypothyroid turkey erythrocytes. (A) Over the most sensitive region of the dose-response curve for isoproterenol (1-16 $\mathrm{nM}$ ), the number of beta receptors occupied (triangles) is shown in relation to the percent of maximally stimulatable potassium transport (circles) for normal (filled symbols) and hypothyroid (open symbols) erythrocytes. The number of beta receptors occupied by specified concentrations of isoproterenol was determined by the known $K_{\mathrm{d}}$ for isoproterenol under these conditions (13) and the relationship $\mathbf{R H}=[\mathrm{H}] \mathrm{R}_{\mathrm{v}}\left([\mathrm{H}]+K_{\mathrm{d}}\right)$, where $\mathrm{RH}$ is the number of occupied receptors per cell, $[\mathrm{H}]$ is the concentration of free hormone, $R_{t}$ is the total number of receptors per cell, and $K_{\mathrm{d}}$ is the equilibrium binding constant. $50 \%$ maximal stimulation of potassium transport is shown by the horizontal line and occurs for both normal and hypothyroid conditions when approximately six to seven receptors are occupied. (B) The number of receptors occupied per cell is plotted against the percentage of maximal isoproterenol-stimulated potassium influx. (O) normal; (O) hypothyroid cells. 
absolute receptor occupancy for both groups of cells. When expressed in terms of absolute receptor occupancy, the effects of isoproterenol on potassium influx in normal and hypothyroid cells are the same. Because, at low concentrations of isoproterenol, absolute receptor occupancy itself is linear with both isoproterenol concentration and total receptor number, a $50 \%$ reduction in beta receptor number in the hypothyroid cell will require twice the hormone concentration needed by a normal cell to achieve a given absolute level of receptor occupancy and physiological response. The shift in the concentration response curve to isoproterenol-stimulated potassium influx in the hypothryoid cell can thus be quantitatively attributed to the reduction in beta-adrenergic receptor number. ${ }^{2}$

Further support for the above conclusions is provided by observations on the concentration of propranolol required to reverse the effects of a maximally stimulatory concentration of isoproterenol on potassium influx. The concentration of propranolol required for half-maximal inhibition of the effects of $100 \mathrm{nM}$ isoproterenol was $72 \mathrm{nM}$ for normal cells but only $24 \mathrm{nM}$ for hypothyroid cells (Fig. 6). The extent to which the sensitivity of the physiological response to isoproterenol is decreased in the hypothyroid cells is thus quantitatively mirrored by the increased sensitivity of the response to propranolol.

\section{DISCUSSION}

The central question addressed in this study was whether the previously reported reduction in betaadrenergic receptor number in hypothyroid turkey erythrocytes is associated with a demonstrable change in physiological responsiveness to isoproterenol. Previous studies showing a decrease in beta-adrenergic receptors in other hypothyroid tissues $(5,7-9,11-13)$ were all restricted to observations of decreased activity

\footnotetext{
${ }^{2}$ For a system involving simple hyperbolic binding between agonist and receptor $\mathrm{RH}=[\mathrm{H}] \mathrm{R}_{\mathrm{t}} /\left([\mathrm{H}]+\boldsymbol{K}_{\mathrm{d}}\right)$, where $\mathrm{RH}$ is the number of occupied receptors per cell, $[\mathrm{H}]$ is the agonist (hormone) concentration, $R_{t}$ the total number of receptors per cell, and $K_{d}$ the dissociation constant for the RH complex. If the physiological response is proportionate to absolute receptor occupancy at low hormone concentrations where $[H] \ll K_{d}$, then $R H \cong[H] R_{t} / K_{d}$, and the slope of the linear response to $[H]$ will be determined by the ratio $R_{\sqrt{ }} K_{\mathrm{d}}$; under such conditions changes in either $R_{t}$ or $K_{d}$ will result, respectively, in either directly or inversely proportional changes in this slope (i.e., a halving of $R_{t}$ will give rise to the same change in slope as would a doubling of $K_{d}$ ). In the instance of the hypothyroid erythrocyte discussed here, $K_{d}$ is shown to be unchanged, and the observed decrease in slope of the physiologic response is found to be quantitatively accounted for by the observed decrease in $\mathbf{R}_{\mathbf{t}}$. Similar relationships have previously been discussed from a theoretical point of view by Williams and Lefkowitz (29).
}

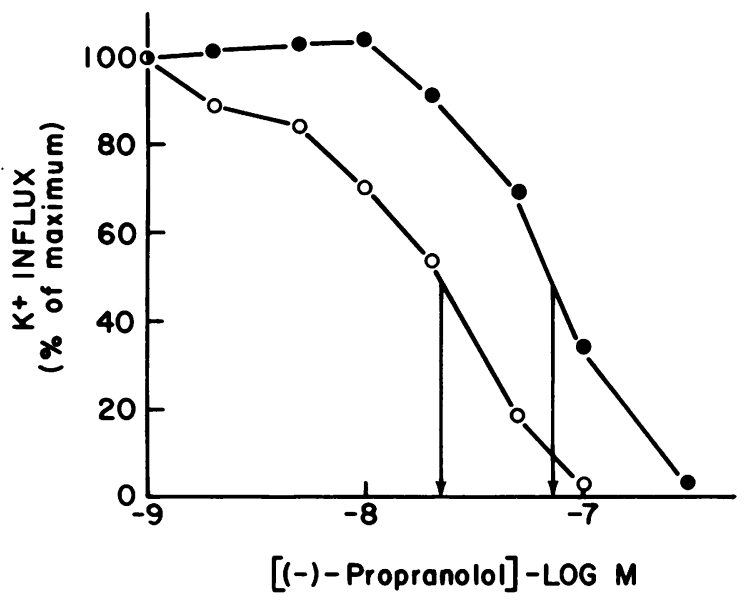

Figure 6 The potency of propranolol as an inhibitor of isoproterenol-stimulatable potassium influx in normal and hypothyroid erythrocytes. Erythrocytes from normal (O) or hypothyroid $(O)$ turkeys were incubated with (-)-isoproterenol $(0.1 \mu \mathrm{M})$ and a range of $(-)$-propranolol concentrations. Blood was pooled from at least two animals in each group and the data points show the means of two separate experiments. $\mathrm{K}^{+}$influx was determined according to Methods. $\mathrm{K}^{+}$concentration $\sim 10 \mathrm{mM}$.

within the beta-adrenergic receptor-adenylate-cyclase complex and did not include possible physiological correlates of these changes. It has therefore remained unclear whether modifications in the beta-adrenergic receptor system now known to be affected in many different hypothyroid models are in fact associated with concomitant changes in physiological sensitivity to the catecholamines. This issue assumes even greater importance in view of observations of others that changes in receptor number do not invariably result in corresponding changes in physiological responsiveness (30). Dissociation between the binding of hormones and their cellular actions has also been shown in several adrenergic systems in which, conversely, altered catecholamine responsiveness occurs despite the absence of any changes in the characteristics of beta-adrenergic receptors $(13,31,32)$.

The results presented here do show that, for the hypothyroid turkey erythrocyte, the reduction in beta receptor number is indeed accompanied by a change in physiological responsiveness to isoproterenol. In contrast to other cells in which thyroid hormone action is mediated, at least in part, through its effects on ion pumps, the decreased sensitivity to catecholaminedependent potassium transport in hypothyroid turkey erythrocyte occurs in the absence of demonstrable alterations in $\mathrm{Na}^{+}-\mathrm{K}^{+}$-ATPase effector units. Four separate lines of evidence support this conclusion: (a) the rate of basal potassium influx over a wide range of potassium concentrations is identical in erythrocytes from normal and hypothyroid birds; $(b)$ 
the magnitude of ouabain-inhibitable potassium influx is the same; $(c)$ ouabain binding affinity and binding capacity are both indistinguishable between normal and hypothyroid cells; and $(d)$ intracellular sodium and potassium concentrations are unchanged in the hypothyroid state.

In interpreting the relationship between reduced receptor number and decreased sensitivity to catecholamine-dependent ion fluxes in hypothyroid turkey erythrocytes, it is important to consider that the normal turkey erythrocyte requires only a very low level of receptor occupancy to give rise to a maximal physiological response. Only $5-10 \%$ of the total receptor number $(300)$, or as few as $15-30$ receptors per cell, is sufficient to generate maximal isoproterenol-stimulated potassium influx (20). The achievement of a maximal response at hormone levels resulting in the occupation of only a small fraction of available receptors has been shown previously in other systems (33-35) and may represent an important mechanism whereby hormone action is finely regulated by permitting a maximal absolute change in receptor occupancy per unit change in hormone concentration. In the present instance of the hypothyroid turkey erythrocyte, the decreased number of beta-adrenergic receptors occurs without a significant change in affinity for agonist binding, so that, at any given low concentration of isoproterenol, fewer receptors in the hypothyroid cell are occupied. Because of this, occupancy of a given, absolute number of beta receptors in the hypothyroid turkey erythrocyte requires a greater concentration of isoproterenol than in the normal cell. Detailed examination of these quantitative relationships has shown that, for a given absolute level of beta receptor occupancy, even though a greater concentration of isoproterenol is required in hypothyroidism, the stimulation of potassium influx by isoproterenol is identical in normal and hypothyroid cells. When $15-30$ receptors are occupied by agonist in either normal or hypothyroid cells, the same maximal stimulation of potassium influx occurs. These observations suggest that the reduction in beta receptor number per se in the hypothyroid turkey erythrocyte can account for its decreased sensitivity to isoproterenol-stimulated potassium influx. In a contrasting study in the hypothyroid rat, Malbon et al. (14) have shown that decreased sensitivity to the lipolytic actions of the catecholamines is not associated with any obvious changes in beta-adrenergic receptors. It has been proposed by these authors that postreceptor events might account for the decreased responsiveness to the catecholamines.

Although the preceding observations on isoproterenol-stimulated potassium influx in the turkey erythrocyte can be attributed simply to the known decrease in beta receptor number, this does not exclude the possibility that in the hypothyroid cell there may exist other accompanying changes in more "distal" components of the sequence of events mediating the physiological response to beta-adrenergic agents. We have already shown, for example, that in addition to the decrease in erythrocyte beta receptor number, isoproterenol-sensitive adenylate cyclase activity and cellular cyclic AMP accumulation are both decreased in hypothyroid cells (13). Additional elements such as the guanine nucleotide binding unit (36) and the protein globlin (37) may eventually also be shown to be modified in hypothyroid turkey erythrocytes. Whether or not these or other intermediate steps mediating catecholamine action are also ultimately shown to be involved, the present observations indicate that the changes in the hypothyroid erythrocyte resulting in the decreased physiological sensitivity of catecholamine-dependent ion flux are probably not associated with other rate-limiting features beyond the reduction in receptor number. It remains to be seen whether this receptor-mediated mechanism, which results in the decreased adrenergic sensitivity of the hypothyroid turkey erythrocyte, applies to other cells as well.

\section{ACKNOWLEDGMENTS}

This work was supported in part by grants HL-20859, HL12738, HD-05506, and training grant TI-AM-07271 from the National Institutes of Health.

\section{REFERENCES}

1. Werner, S. C. 1978. Hyperthyroidism. In The Thyroid. S. C. Werner and S. H. Ingbar, editors. Harper \& Row, Publishers; Inc., New York. 4th edition. 591-603.

2. Rosenqvist, U. 1972. Noradrenalin-induced lipolysis in subcutaneous adipose tissue from hypothyroid subjects. Acta Med. Scand. 192: 301-308.

3. Deykin, D., and.M. Vaughan. 1963. Release of free fatty acids by adipose tissue from rats treated with triiodothyronine or propylthiouracil. J. Lipid Res. 4: 200-203.

4. Williams, L. T., R. J. Lefkowitz, A. M. Watanabe, D. R. Hathaway, and H. R. Besch, Jr. 1977. Thyroid hormone regulation of $\beta$-adrenergic receptor number. J. Biol. Chem. 252: 2787-2789.

5. Ciaraldi, T., and G. V. Marinetti. 1977. Thyroxine and propylthiouracil effects in vivo on alpha and beta adrenergic receptors in the heart. Biochem. Biophys. Res. Commun. 74: $984-991$.

6. Kempson, S., G. V. Marinetti, and A. Shaw. 1978. Stimulation of dihydroalprenolol binding to beta-adrenergic receptors in isolated rat heart ventricle slices by triiodothyronine and thyroxine. Biochim. Biophys. Acta. 540: 320-329.

7. Banerjee, S. P., and L. S. Lung. 1977. $\beta$-Adrenergic receptors in rat heart: effects of thyroidectomy. Eur. J. Pharmacol. 43: 207-208.

8. Sharma, V. K., and S. P. Banerjee. 1978. $\beta$-Adrenergic receptors in rat skeletal muscle: effects of thyroidectomy. Biochim. Biophys. Acta. 539: 538-542.

9. Smith, R. M., W. S. Osborne-White, and R. A. King. 1978. Changes in the sarcolemma of the hypothyroid heart. Biochem. Biophys. Res. Commun. 80: 715-721. 
10. Tsai, J. S., and A. Chen. 1978. Effect of L-triiodothyronine on $(-)^{3} \mathrm{H}$-dihydroalprenolol binding and cyclic AMP response to (-)adrenaline in cultured heart cells. Nature (Lond.). 275: 138-140.

11. Guidicelli, Y. 1978. Thyroid-hormone modulation of the number of $\beta$-adrenergic receptors in rat fat-cell membranes. Biochem. J. 176: 1007-1010.

12. McConnaughey, M. M., L. R. Jones, A. M. Watanabe, H. R. Besch, Jr., L. T. Williams, and R. J. Lefkowitz. 1979. Thyroxine and propylthiouracil effects on alpha- and beta-adrenergic receptor number, ATPase activities, and sialic-acid content of rat cardiac membrane vesicles. J. Cardiovasc. Pharmacol. 1: 609-623.

13. Bilezikian, J. P., J. N. Loeb, and D. E. Gammon. 1979. The influence of hyperthyroidism and hypothyroidism on the $\beta$-adrenergic responsiveness of the turkey erythrocyte. J. Clin. Invest. 63: 184-192.

14. Malbon, C. C., F. J. Moreno, R. J. Cabelli, and J. N. Fain. 1978. Fat cell adenylate cyclase and $\beta$-adrenergic receptors in altered thyroid states. J. Biol. Chem. 253: $671-678$.

15. Williams, R. S., C. E. Guthrow, and R. J. Lefkowitz. 1979. $\beta$-Adrenergic receptors of human lymphocytes are unaltered by hyperthyroidism. J. Clin. Endocrinol. Metab. 48: 503-505.

16. Bilezikian, J. P. 1976. The interrelationship between $\beta$-adrenergic receptors and adenylate cyclase activity in the turkey erythrocyte. In Modern Pharmacology. Gerald S. Levy, editor. Marcel Dekker, Inc. New York. 349-371.

17. Gardner, J. D., H. L. Klaeveman, J. P. Bilezikian, and G. D. Aurbach. 1973. Effect of $\beta$-adrenergic catecholamines upon sodium transport in the turkey erythrocyte. J. Biol. Chem. 248: 5590-5596.

18. Schmidt, W. F., and T. J. McManus. 1977. Ouabaininsensitive salt and water movement in duck red cells. II. Norepinephrine stimulation of sodium plus potassium cotransport. J. Gen. Physiol. 70: 81-97.

19. Rudolph, S. A., Schafer, D. E., and P. Greengard. 1977. Effects of cholera enterotoxin on catecholaminestimulated changes in cation fluxes, cell volume, and cyclic AMP levels in the turkey erythrocyte. J. Biol. Chem. 252: 7132-7139.

20. Furukawa, H., J. P. Bilezikian, and J. N. Loeb. 1980. Effects of ouabain and isoproterenol on potassium influx in the turkey erythrocyte: quantitative relation to ligand binding and cyclic AMP generation. Biochim. Biophys. Acta. 598: 345-356.

21. Edelman, I. S., and F. Ismail-Beigi. 1974. Thyroid thermogenesis and active sodium transport. Recent Prog. Horm. Res. 30: 235-257.

22. Remington, R. E. 1937. Improved growth in rats on iodine-deficient diets. J. Nutr. 13: 223-233.
23. Bilezikian, J. P., J. N. Loeb, and D. E. Gammon. 1980. Induction of sustained hyperthyroidism and hypothyroidism in the turkey: physiological and biochemical observations. Poult. Sci. 59: 628-634.

24. Davidsohn, I., and D. A. Nelson. 1974. Colorimetric methods. In Clinical Diagnosis by Laboratory Methods. I. Davidsohn and J. B. Henry, editors. W. B. Saunders, Co., Philadelphia. 15th edition. 106-110.

25. Gardner, J. D., R. S. Mensh, D. R. Kiino, and G. D. Aurbach. 1975. Effect of $\beta$-adrenergic catecholamines on potassium transport in turkey erythrocytes. J. Biol. Chem. 250: 1155-1163.

26. Bray, G. A. 1960. A simple efficient liquid scintillator for counting aqueous solutions in two liquid scintillation counts. Anal. Biochem. 1: 279-285.

27. Sachs, J. R., and L. G. Welt. 1967. The concentration dependence of active potassium transport in the human red blood cell. J. Clin. Invest. 46: 65-76.

28. Scatchard, G. 1949. The attractions of proteins for small molecules and ions. Ann. N. Y. Acad. Sci. 51: 660-672.

29. Williams, L. T. and R. J. Lefkowitz. 1978. Regulation and adrenergic receptors. In Receptor Binding Studies in Adrenergic Pharmacology. Raven Press, New York. $127-130$

30. Kolterman, O. G., M. Greenfield, G. M. Reaven, M. Saekow, and J. M. Olefsky. 1979. Effect of a high carbohydrate diet on insulin binding to adipocytes and insulin action in vivo in man. Diabetes. 28: 731-736.

31. Bilezikian, J. P., A. M. Spiegel, E. M. Brown, and G. D. Aurbach. 1977. Identification and persistence of $\beta$ adrenergic receptors during maturation of the rat reticulocyte. Mol. Pharmacol. 13: 775-785.

32. Beckman, B. S., and M. D. Hollenberg. 1979. Betaadrenergic receptors and adenylate cyclase activity in rat reticulocytes and mature erythrocytes. Biochem. Pharmacol. 28: 239-248.

33. Terasaki, W. L., and G. Brooker. 1978. [ [125I]Iodohydroxybenzylpindolol binding sites on intact rat glioma cells. J. Biol. Chem. 253: 5418-5425.

34. Mendelson, D., M. Dufau, and K. Catt. 1975. Gonadotropin binding and stimulation of cyclic adenosine $3^{\prime}, 5^{\prime}$-monophosphate and testosterone production in isolated Leydig cells. J. Biol. Chem. 250: 8818-8823.

35. Olefsky, J. M. 1976. The insulin receptor: its role in insulin resistance of obesity and diabetes. Diabetes. 25: $1154-1162$

36. Malbon, C. C., and D. M. Gill. 1979. ADP-ribosylation of membrane proteins and activation of adenylate cyclase by cholera toxin in fat cell ghosts from euthyroid and hypothyroid rats. Biochim. Biophys. Acta. 586: 518-527.

37. Alper, S. L., K. G. Beam, and P. Greengard. 1980. Hormonal control of $\mathrm{Na}^{+}-\mathrm{K}^{+}$co-transport in turkey erythrocytes. J. Biol. Chem. 255: 4864-4871. 